\title{
INVESTIGASI KARAKTERISTIK TONER HASIL VARIASI PERSENTASE NANO CARBON BLACK
}

\author{
TONER CHARACTERISTIC INVESTIGATION \\ RESULTS OF NANO CARBON BLACK PERCENTAGE VARIATION
}

\author{
Sulton Amna ${ }^{1)}$ \\ ${ }^{1)}$ Program Studi Teknik Pengolahan Migas Politeknik Akamigas Palembang, 30257, Indonesia \\ Corresponding Author E-mail: sulton@pap.ac.id
}

\begin{abstract}
Carbon black (CB) is an important material used as a dye and functional materials that are used as a toner. $\mathrm{CB}$ particles in nano-meter size is expected to produce a toner with patterns of distribution and uniform dispersion. Synthesis of toner carried by 3 weight variation of nano CB 10, 15 and $20 \%$ were in the ball mill with styrene/ acrylate copolymer (KSA), black oxide (BO) and water. The resulted powder has been characterized through a series of tests, such as testing of the X-Ray Diffraction (XRD), Fourier Transform Infrared (FTIR) the tests of magnetic susceptibility and Scanning Electron Microscopy / Energy Dispersive X-ray Spectroscopy (SEM / EDX). The results showed that the $\mathrm{CB}$ in nanometers size has an important role on the characteristic of toner. SEM characterization results indicate that the toner $10 \mathrm{CB}$ has the size and the most uniform distribution. XRD results showed phase $\mathrm{Fe}_{3} \mathrm{O}_{4}$ (magnetite) which has ferrimagnetic properties that determine the value of magnetic susceptibility. The average of magnetic susceptibility of synthesized toner $10 \mathrm{CB}, 15 \mathrm{CB}$ and $20 \mathrm{CB}$ is $10223,13 \times 10^{-8}, 9983,2 \times 10^{-8}, 11083,67 \times 10^{-8} \mathrm{~m}^{3} / \mathrm{kg}$. The best characteristic was shown by $10 \mathrm{CB}$ toner synthesis results which have uniform in size and shape, and have high magnetic susceptibility.
\end{abstract}

Keywords: Toner, nano carbon black, ball mill, characteristic

Abstrak: Carbon black (CB) merupakan material penting yang digunakan sebagai pewarna dan material fungsional yang digunakan sebagai toner. Partikel CB dalam ukuran nano meter diharapkan mampu menghasilkan toner dengan pola distribusi dan dispersi yang merata. Sintesis toner dilakukan dengan 3 variasi persentase nano CB 10, 15 dan 20 $\%$ yang di ball mill dengan kopolimer stirenal akrilat (KSA), Black Oxide (BO) dan air. Serbuk toner yang telah disintesis dikarakterisasi melalui serangkaian pengujian, seperti pengujian X-Ray Diffraction (XRD), pengujian Fourier Transform Infrared (FTIR), pengujian suseptibilitas magnetik dan pengujian Scanning Electron Microscopy/Energy Dispersive X-ray Spectroscopy (SEM/EDX). Hasil penelitian menunjukkan bahwa CB dalam orde nanometer memiliki peran penting terhadap karakteristik toner. Hasil karakterisasi SEM menunjukkan bahwa toner 10 $\mathrm{CB}$ memiliki ukuran dan distribusi yang paling seragam. Hasil XRD menunjukkan fase $\mathrm{Fe}_{3} \mathrm{O}_{4}$ (magnetit) yang memiliki sifat ferrimagnetik yang menentukan nilai suseptibilitas magnetik. Hasil uji suseptibilitas magnetik menunjukkan nilai

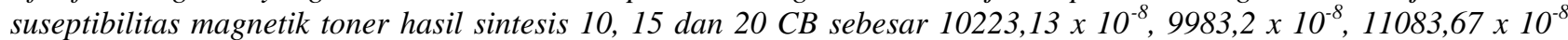
$\mathrm{m}^{3} / \mathrm{kg}$. Karakteristik terbaik ditunjukkan oleh toner $10 \mathrm{CB}$ hasil sintesis dengan bentuk dan ukuran yang seragam serta memiliki nilai suseptibilitas magnetik yang tinggi.

Kata kunci : Toner, nano carbon black, ball mill, karakteristik.

\section{PENDAHULUAN}

Perkembangan dunia yang begitu dinamis di segala sisi, menjadi tantangan tersendiri bagi bidang ilmu pengetahuan dan teknologi. Di zaman yang serba cepat, tepat dan hemat, setiap orang mencari proses yang efektif serta efisien. Efisiensi menjadi mutlak, mengingat gencarnya penelitian dibidang rekayasa material sehingga didapatkan maerial yang efektif dan efisien untuk fungsi tertentu.

Berdasarkan hasil survei yang dilakukan oleh International Data Corporation
(IDC) tahun 2013, bahwa pada tahun 2012 penjualan toner catridges mencapai angka $42 \%$ di wilayah Eropa. IDC mengestimasi bahwa pada tahun 2014, negara-negara di Eropa, Timur Tengah dan Afrika merupakan pasar yang sangat potensial untuk penjualan toner catridges dan diprediksi nilainya mencapai 3 milyar dollar ${ }^{[1]}$. Dengan angka yang sebesar itu dan diprediksi akan terus mengalami peningkatan seiring dengan perkembangan teknologi cetak, potensi 
pengembangan rekayasa formulasi toner sangat menjanjikan.

Printer (alat cetak) dengan toner catridges lebih disukai karena memiliki beberapa keuntungan, yaitu memiliki efisiensi yang lebih baik dari printer tinta cair, dan kecepatan cetaknya mencapai 8 sampai 24 hpm (halaman per menit) dengan resolusi 300600 dpi (dots per inch $)^{[2]}$.

Toner (tinta serbuk) merupakan bahan berbentuk serbuk yang digunakan dalam mesinfotokopi atau printer $\operatorname{laser}^{[3]}$ dan sekurang-kurangnya memiliki tiga komponen utama $^{[4]}$, yaitu: pigmen sebagai zat warna, resin sebagai pengikat, dan pelarut. Pemilihan komponen-komponen tersebut harus mengacu kepada beberapa hal berikut, yaitu memiliki viskositas yang rendah dan bahan pelarutnya relatif mudah menguap, agar pada saat pencetakan, pemanasan yang dilakukan oleh pelebur (fuser) akan menyebabkan pelarut menguap sehingga resin yang terkandung didalamnya akan mengatur pigmen-pigmennya pada substrat cetakan ${ }^{[4,5]}$. Pada awal perkembangannya, serbuk toner adalah karbon biasa $^{[6]}$, namun seiring dengan kemajuan teknologi digunakanlah campuran karbon dengan polimer dan pigmen untuk meningkatkan kualitas cetakan. Toner terdiri dari serbuk halus yang berukuran kecil (8 $10 \mu \mathrm{m})$ dan dibungkus oleh mineral tipis yang mengandung magnetik tampak seperti besi oksida dan berwarna hitam, sehingga dapat menghasilkan hasil cetak yang baik ${ }^{[7]}$. Toner yang memiliki ukuran butir yang lebih kecil akan menghasilkan cetakan yang lebih baik ${ }^{[8]}$, hal ini selaras dengan teori hukum Grunlach yang menunjukkan bahwa ukuran partikel toner dan densitas dot pada pencetak digital memiliki hubungan inverse exponential ${ }^{[9]}$. Teorinya, untuk menghasilkan kualitas cetak 600 dpi yang sempurna diperlukan partikel toner berukuran $5 \mu \mathrm{m}$, dan untuk menghasilkan kualitas cetak 1200 dpi yang baik diperlukan partikel toner berukuran $3 \mu \mathrm{m}$. Untuk meningkatkan kualitas cetakan, maka harus dilakukan pengontrolan terhadap beberapa karakteristik serbuk toner, seperti ukuran dan bentuk partikel, sifat leleh termal, prilaku adesif dan mampu alirnya ${ }^{[10,11]}$.

Carbon black (CB) merupakan material penting yang digunakan sebagai pewarna dan material fungsional yang digunakan sebagai toner ${ }^{[12]}$. CB dapat digunakan sebagai penguat ban, agen anti-UV, pigmen pada tinta, cat, dan toner ${ }^{[13]}$. CB tersusun dari 90-99\% elemen karbon, terbentuk dalam agregat dengan ukuran terkecil yang bervariasi antara 50 hingga 500 $\mathrm{nm}$ dan memiliki bentuk yang tidak beraturan. Agregat-agregat ini tersusun dalam partikel yang berbentuk bulat dengan diameter $10-75$ $\mathrm{nm}^{[14]}$. Partikel $\mathrm{CB}$ dalam ukuran tertentu diharapkan mampu menghasilkan pola distribusi dan dispersi yang merata sehingga dapat mengurangi persentase penggunaan $\mathrm{CB}$ didalam formulasi toner dengan tetap menjaga bahkan meningkatkan kualitas cetak yang dihasilkan.

Dengan mempertimbangkan adanya korelasi antara ukuran carbon black (CB) dan karakteristik toner, maka diperlukan penelitian untuk mengetahui karakteristik toner yang dihasilkan setelah melakukan variasi ukuran toner. Berdasarkan penelitian yang telah dilakukan sebelumnya ${ }^{[15]}$ bahwa ukuran dan komposisi pigmen partikel black oxide (BO) memiliki pengaruh signifikan terhadap kualitas toner, maka dalam penelitian ini dilakukan investigasi untuk menganalisis pengaruh ukuran $\mathrm{CB}$ terhadap karakteristik toner yang dihasilkan.

\section{TEORI DASAR}

\subsection{Mesin Fotokopi dan Printer Laser}

Mesin fotokopi dan printer laser dalam proses kerjanya menggunakan proses elektrofotografi untuk menghasilkan gambar/tulisan. Sehingga tidak mengejutkan jika kedua proses ini memiliki kesamaan proses dan hasil. Akan tetapi keduanya juga memiliki perbedaan, perbedaan mendasar antara keduanya, yaitu mesin fotokopi hanya dapat menghasilkan gambar dengan cara menyalin gambar yang sudah ada dimana laser/cahaya dioda memproduksi dokumen salinan dengan mencetak tulisan/gambar dari 
komputer atau microsoft word. Sedangkan printer laser, harus berhubungan langsung dengan komputer untuk menjalankan fungsinya ${ }^{[16]}$.

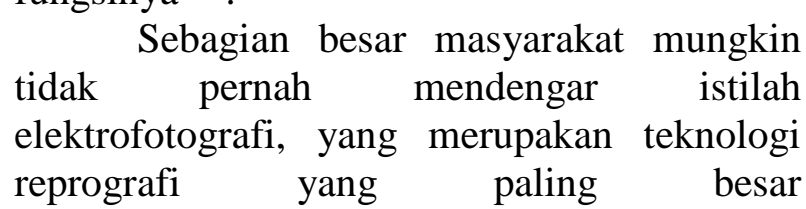
perkembangannya. Pernyataan ini akan berubah seketika ketika elektrofotografi dikaitkan dengan teknologi yang cukup familiar ditengah masyarakat yaitu, mesin fotokopi dan printer laser.Keduanya merupakan teknologi yang dikembangkan dengan menggunakan proses elektrofotografi, yaitu proses pencetakan menggunakan tinta serbuk ke media cetak/kertas dengan memanfaatkan cahaya/laser yang memancar ke dioda.

Kebutuhan akan proses cetak yang cepat dan efisien, membuat keduanya baik mesin fotokopi maupun printer laser menjadi sesuatu yang penting ditengah-tengah masyarakat, sehingga riset dan pengembangannya terus dilakukan hingga saat ini. Teknologi yang juga berkaitan dengan proses elektrofotografi adalah Photoactive Pigment Electrophoresis (PAPE), yang juga dikenal sebagai Photoelectrophoretic (PEP) imaging. Teknologi ini mengkombinasikan prinsip elektrofotografi dan Elektroforesis yang mampu memproduksi gambar/tulisan dengan gambar penuh dengan 1 kali proses, sehingga membuat proses penyalinan gambar/tulisan gambar penuh dengan lebih cepat dan simpel ${ }^{[16]}$.

\subsection{Toner}

Toner dapat berupa serbuk kering dengan satu atau dua komponen toner, ataupun cairan. Hingga saat ini, penelitian toner kering dengan dua komponen lebih banyak dilakukan dibanding dengan toner cair ataupun toner kering dengan satu komponen ${ }^{[16]}$. Toner banyak digunakan didalam berbagai proses, sebagai pembuat dan penduplikasi gambar. Toner berfungsi sebagai pembentuk gambar tersembunyi dari aliran listrik yang selanjutnya ditransfer menuju material cetak (kertas) dan difiksasi menggunakan panas dan tekanan ${ }^{[17]}$. Berikut ini merupakan beberapa jenis toner yang digunakan dalam pencetakan ${ }^{[17]}$ :

1. Toner magnetik dengan satu komponen, mengandung satu komponen serbuk magnetik.

2. Toner non magnetik dengan satu komponen, mengandung satu komponen serbuk non magnetik

3. Toner non magnetik dengan dua komponen, mengandung satu komponen serbuk magnetik dan satu komponen pembawa sifat magnet yang dicampur dalam toner dengan komposisi tertentu

4. Toner dengan dua komponen magnetik, mengandung satu komponen serbuk magnetik dan satu komponen pembawa sifat magnet yang dicampur dalam toner dengan komposisi tertentu.

Berbagai perkembangan metode pembuatan toner hingga saat ini terus dilakukan untuk memperoleh toner dengan performa tinggi. Toner yang saat ini sedang dikembangkan adalah dengan metode pulverizing suatu agen pewarna seperti zat warna atau pigmen yang dicampur dengan resin termoplastik sebagai pengikat. Campuran yang diperoleh selanjutnya diklasifikasi untuk menghasilkan distribusi ukuran partikel yang seragam.

\subsection{Komponen toner}

Toner sekurang - kurangnya mengandung suatu resin atau toner resin, pewarna atau pigmen, dan beberapa zat tambahan lainnya sebagai agen pelepas dan pengendali. Beberapa polimer yang sering digunakan untuk membuat toner, yaitu resin termoplastik seperti polistirene, stirena akrilik, stirena metakrilik, poliester, epoxy, acrilik dan uretan. Contoh pewarna yang sering digunakan, yaitu: carbon black, iron black, grafit, nigrosine, ultramarine, metilen biru, benzen kuning, dan beberapa tipe pigmen lain. Ketika pewarna tidak mengandung sifat magnet, jumlahnya harus berkisar antara 1 $30 \%$, dan pewarna dapat dilapisi menggunakan penstabil UV. 


\section{METODOLOGI PENELITIAN}

Toner merupakan gabungan tiga komponen utama, yaitu: pigmen, resin dan pelarut. Untuk memperoleh karakteristik yang optimal, dibutuhkan sebuah formulasi khusus antara ketiga komponen tersebut. Pada proses pencarian formulasi yang optimal ini dilakukan uji SEM EDAX untuk mengetahui persentase karbon yang terkandung dalam karbon hitam. Sintesis toner dilakukan dengan melakukan mixing antara carbon black dengan variabel 10, 15 dan $20 \mathrm{wt} \%$, kopolimer stirena akrilik, air dan black oxide dilakukan dengan menggunakan alat mixing agar toner yang dihasilkan memiliki tingkat homogenisasi dan ukuran partikel yang merata dan seragam. Setelah proses pencampuran selesai, dilakukan proses pengeringan. Setelah toner kering, dilakukan proses milling menggunakan ball mill. Karakterisasi toner yang terbentuk dengan menggunakan SEM, XRD, pengujian suseptibilitas magnetik dan FTIR.

\section{HASIL DAN PEMBAHASAN}

Sintesis toner dilakukan dengan melakukan variasi carbon black sebesar 10, 15 dan 20 wt\%. Berikut merupakan hasil uji komposisi bahan baku yang digunakan, karakterisasi toner menggunakan SEM, XRD, uji suseptibilitas magnetik dan FTIR.

\subsection{Uji komposisi}

Sebelum melakukan proses sintesis toner, bahan baku pembuat toner yang digunakan pada penelitian ini terlebih dahulu dilakukan uji komposisi menggunakan SEM EDX dan XRD untuk mengetahui tingkat kemurnian dan komposisinya.

Gambar 4.1 menunjukkan grafik dari material carbon black yang digunakan pada sintesis toner. Hasil tersebut menunjukkan bahwa kandungan karbon pada carbon black mencapai $95,58 \%$ dengan kadar pengotor berupa oksigen yang diduga memang terdapat di sekitar sebesar 4,42\%. Hal ini menunjukkan bahwa tingkat kemurnian carbon black sangat tinggi dan layak digunakan sebagai salah satu komponen penyusun toner.

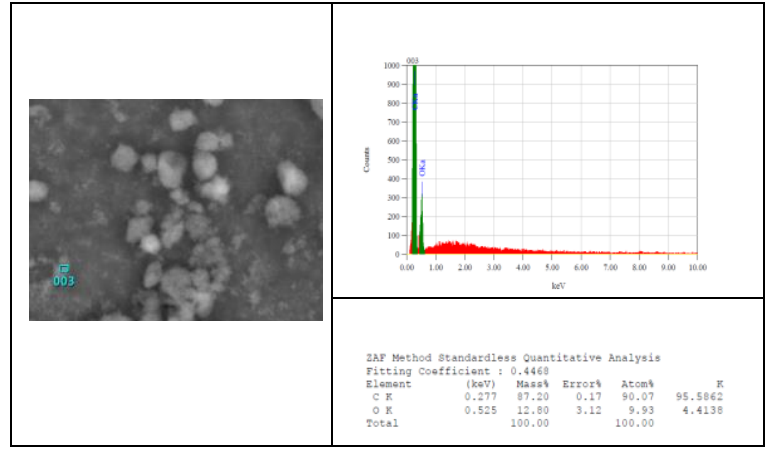

Gambar 4.1 Hasil Uji SEM EDX pada Carbon Black

\subsection{Karakterisasi Toner}

Karakterisasi toner dilakukan untuk mengetahui kandungan senyawa dan morfologi dari toner yang telah di sintesis.

\subsubsection{Analisis data XRD}

Pengujian XRD dilakukan dengan menggunakan radiasi monokromatik $\mathrm{Cu} \mathrm{K \alpha}$ $(\lambda=1,54056 \AA ̊ ́)$. Pengujian ini menghasilkan grafik yang memaparkan hubungan antara intensitas terhadap posisi $2 \theta$. Dari posisi $2 \theta$, dapat diketahui senyawa yang terbentuk dari sintesis toner yang dibuat. Gambar 4.2 dibawah ini menunjukkan hasil uji XRD toner 10, 15, dan $20 \mathrm{CB}$ dan hasil uji XRD toner komersial.

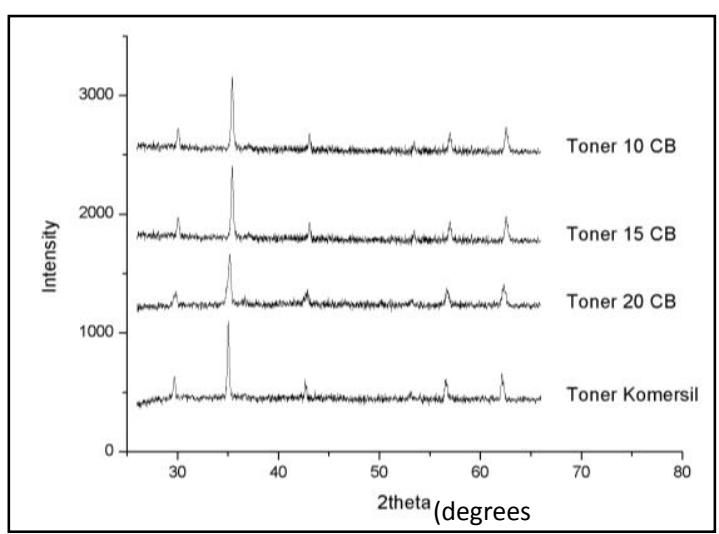

Gambar 4.2 Hasil Uji XRD Toner dengan Variasi CB

Analisis kualitatif dari data XRD dilakukan menggunakan software Match dan dicocokkan dengan data base Crystallography Open Data Base COD. Hasil pengujian menunjukkan bahwa toner, baik toner hasil sintesis maupun toner komersil hanya 
memiliki satu fasa yang terkandung, yaitumagnetit $\left(\mathrm{Fe}_{3} \mathrm{O}_{4}\right)$ kode 96-901-3530. Hal ini sesuai dengan penelitian yang dilakukan oleh Irvan $^{[17]}$ dan Tanauma ${ }^{[18]}$ yang menyatakan bahwa fase yang terbentuk dari karakterisasi toner adalah $\mathrm{Fe}_{3} \mathrm{O}_{4}$ (magnetite). Hal ini menunjukan bahwa toner mengandung pasir besi yang merupakan pasir besi hematite $\left(\mathrm{Fe}_{3} \mathrm{O}_{4}\right)$ yang berasal dari bahan tambahan berupa besi oksida yang di ekstraksi dari pasir besi . Dari hasil XRD tampak bahwa fase yang terbentuk sudah hampir sesuai dengan yang diharapkan berdasarkan teori dan sudah membentuk fase yang hampir sama dengan fase toner yang ada di pasaran. Fase inilah yang kemudian berperan dalam menentukan nilai suseptibilitas magnetik toner karena bersifat ferrimagnetik, sesuai dengan hasil yang diteliti oleh Lestyowati ${ }^{[19]}$.

Dari grafik XRD, dapat juga diketahui besar ukuran kristalit yang dihasilkan. Ukuran kristalit ini yang mempengaruhi besarnya nilai suseptibilitas magnetiknya. Besar ukuran kristalit material toner dapat dihitung dengan menggunakan besar pelebaran total atau broadening sampel pada hasil pengujian XRD dengan menggunakan metode Scherrer. Tabel 4.1 merupakan hasil perhitungan ukuran kristalit menggunakan metode Scherrer.

Tabel 4.1 Hasil Pengukuran Nilai Kristalit Material Toner dengan Variasi CB

\begin{tabular}{|l|l|}
\hline Sampel & Ukuran kristalit $(\mu \mathrm{m})$ \\
\hline Toner 10 CB & 10,18 \\
\hline Toner 15 CB & 10,15 \\
\hline Toner 20 CB & 12,58 \\
\hline Toner Komersial & 11,57 \\
\hline
\end{tabular}

Dari tabel hasil pengukuran diatas terlihat bahwa ukuran rata-rata kristalit partikel toner $20 \mathrm{CB}$ adalah yang paling besar, yaitu sebesar $12,58 \mu \mathrm{m}$. Sedangkan ukuran kristalit toner 10 dan $15 \mathrm{CB}$ lebih kecil dari toner komersial.

\subsubsection{Analisis Hasil SEM}

Pengujian ini bertujuan untuk mengamati dan mempelajari morfologi dan ukuran material. Pengujian SEM ini dilakukan di PTBIN BATAN, Puspiptek, Serpong. Gambar 4.3, 4.4 dan 4.5 berturut-turut merupakan hasil SEM dari toner 10, 15, dan 20 wt\% CB dan gambar 4.6 merupakan hasil SEM toner komersil.

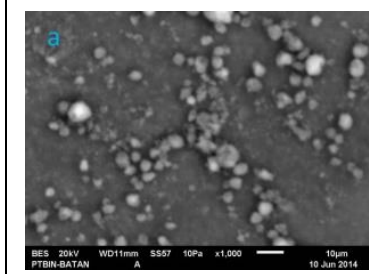

(a)

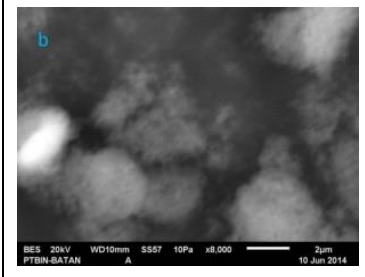

(b)
Gambar 4.3 Hasil Pengujian SEM Sampel Toner $10 \mathrm{CB}$ dengan perbesaran: (a) 1000 dan (b) 8000 kali

Dari hasil uji SEM pada sampel toner $10 \mathrm{CB}$ di atas, terlihat bahwa sampel memiliki bentuk morfologi yang spherical dan distribusi ukuran yang merata dan seragam. Rata-rata toner memiliki ukuran 5-8 $\mu \mathrm{m}$ dan mendekati ukuran partikel toner komersial.

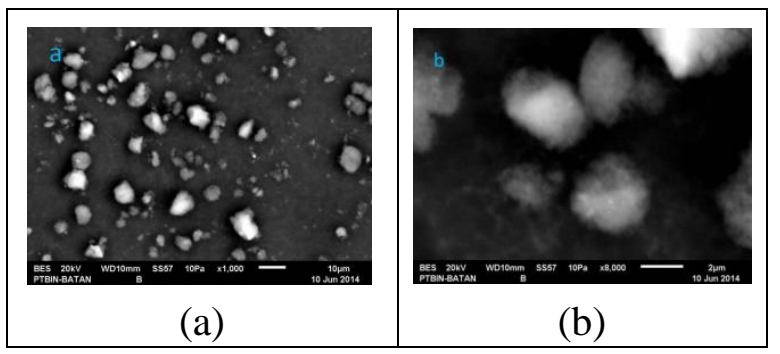

Gambar 4.4 Hasil Pengujian SEM sampel toner $15 \mathrm{CB}$ dengan perbesaran:

(a) 1000 dan (b) 8000 kali

(b)

Dari hasil uji SEM pada sampel toner $15 \mathrm{CB}$ diatas, terlihat bahwa sampel memiliki bentuk morfologi yang spherical tidak merata dan distribusi ukuran yang merata dan seragam. Ukuran rata-rata partikel toner 1-8 $\mu \mathrm{m}$.

Dari gambar 4.5 hasil uji SEM pada sampel toner $20 \mathrm{CB}$ tersebut, terlihat bahwa sampel memiliki bentuk morfologi yang bulat dan ada beberapa yang berbentuk batang ( $r o d$ ) dan distribusi ukuran yang tidak seragam. Rata-rata toner memiliki ukuran $5-10 \mu \mathrm{m}$. 


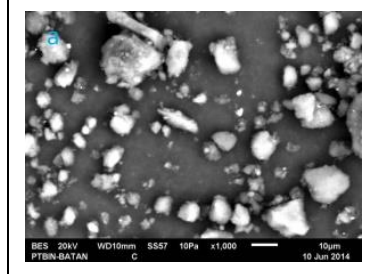

(a)

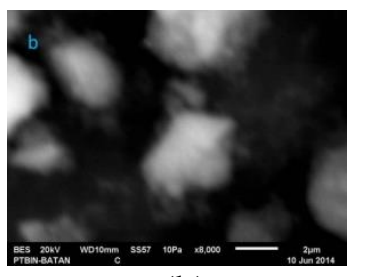

(b)
Gambar 4.5 Hasil Pengujian SEM Sampel Toner 20 CB dengan Perbesaran:

(a) 1000 dan (b) 8000 kali

Dari perbandingan hasil toner $10 \mathrm{CB}, 15$ $\mathrm{CB}, 20 \mathrm{CB}$ dan toner komersial, diperoleh hasil yang tidak jauh berbeda baik bentuk maupun ukurannya terhadap toner komersil. Akan tetapi, pada toner sampel 3 terlihat bahwa bentuk toner menyerupai batang. Ini dikarenakan formulasi yang dibuat pada sampel 3 mengandung terlalu banyak carbon black, sehingga mengakibatkan penggumpalan / aglomerat carbon black pada saat proses pencampuran dengan polimer dan bahan lainnya.

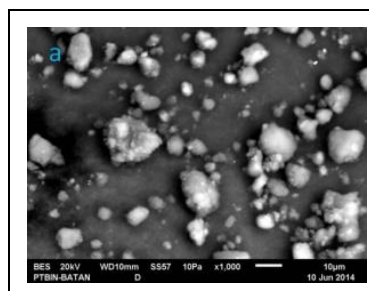

(a)

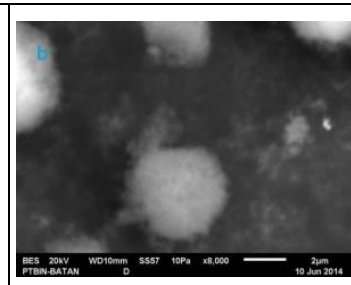

(b)
Gambar 4.6 Hasil Pengujian SEM Toner Komersial dengan Perbesaran:

(a) 1000 dan (b) 8000 kali

\subsubsection{Analisis Hasil FTIR}

Uji FTIR menggunakan kalium bromida (KBr) sebagai bahan campuran sampel agar dapat terdeteksi dan menggunakan serapan gelombang sebesar $4.000-400 / \mathrm{cm}$. Gambar 4.7 berikut ini merupakan grafik hasil uji FTIR dari 3 sampel hasil sintesis dan toner komersial.

Dari hasil uji FTIR, terlihat bahwa toner hasil sintesis memiliki komposisi yang sama dengan toner komersial, yaitu berbasis kopolimer stirena akrilik karena memiliki grafik spektroskopi yang hamper sama. Pada serapan gelombang $3.700 / \mathrm{cm}$ merupakan serapan gelombang black oxide $\left(\mathrm{Fe}_{3} \mathrm{O}_{4}\right)$, hal ini sesuai dengan buku referensi spektroskopi vibrasi $^{[20]}$.

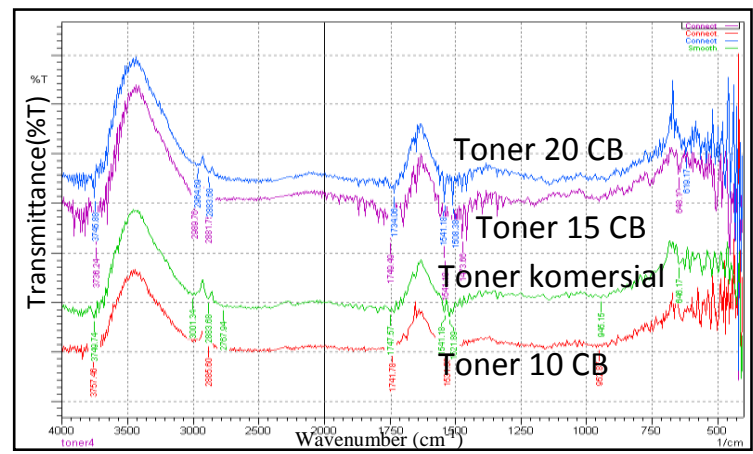

Gambar 4.7 Hasil Uji FTIR Sampel Toner dengan Variasi CB

Pada serapan gelombang 2.800 dan $2.900 / \mathrm{cm}$ merupakan serapan gelombang milik karbon (C) dan serapan pada 1.700 dan 1.500 /cm merupakan serapan senyawa kopolimer stirena akrilik. Namun, pada serapan 1.700, terbentuk gugus karbonil (CO) seperti penelitian yang dilakukan oleh Vikman dan Sipi ${ }^{[20]}$.

\subsubsection{Uji Suseptibilitas magnetik}

Uji suseptibilitas magnetik toner menggunakan alat Bartingtong Magnetic Susceptibility Meter MS2B berbasis massa. Nilai suseptibilitas magnetik dari ketiga sampeltoner hasil sintesis dan toner komersil dapat dilihat pada tabel 2 dibawah ini.

Tabel 4.3 Nilai Suseptibilitas Magnetik Sampel Toner dengan Variasi CB

\begin{tabular}{|l|c|c|c|}
\hline Sampel & $\begin{array}{l}\text { Massa } \\
\text { (gram) }\end{array}$ & $\begin{array}{l}\text { Nilai } \\
\text { suseptibilitas } \\
\text { magnetik } \\
\left(10^{-4} \mathrm{~m}^{3} / \mathrm{kg}\right)\end{array}$ & $\begin{array}{l}\text { Nilai } \\
\text { suseptibilitas } \\
\text { rata-rata } \\
\left(10^{-4} \mathrm{~m}^{3} / \mathrm{kg}\right)\end{array}$ \\
\hline Toner 10 CB & 1 & 1,03 & \\
& 1 & 0,98 & 1,02 \\
\hline \multirow{3}{*}{ Toner 15 CB } & 1 & 1,05 & \\
& 1 & 0,97 & 0,99 \\
\hline \multirow{3}{*}{ Toner 20 CB } & 1 & 1,99 & \\
& 1 & 1,09 & 1,11 \\
\hline Toner & 1 & 1,12 & \\
komersil & 1 & 1,17 & 1,15 \\
\hline
\end{tabular}


Berdasarkan hasil pengujian, semua sampel toner hasil sintesis berindikasi memiliki sifat magnetik yangkuat, dikarenakan kandungan $\mathrm{Fe}_{3} \mathrm{O}_{4}$ yang bersifat ferrimagnetik. Bahan ferrimagnetik ini memiliki suseptibilitas magnetik besar dan berharga positif. Nilai suseptibilitas magnetik toner 10 , 15 dan 20wt\% CB tidak jauh berbeda dengan nilai suseptibilitas magnetik toner komersil. Ini mengindikasikan bahwa sifat magnetik toner hasil sintesis menyamai toner komersil.

Hasil XRD (Gambar 4.8) menunjukkan adanya senyawa $\mathrm{Fe}_{3} \mathrm{O}_{4}$ (magnetite) yang bersifat ferrimagnetik. Senyawa inilah yang memberikan efek suseptibilitas magnetik yang besar dan harganya positif. Sifat ini timbul karena elektron-elektronnya tidak berpasangan dan spinnya tersusun antiparalel sehingga meghasilkan momen magnet yang cukup besar $^{[21]}$.

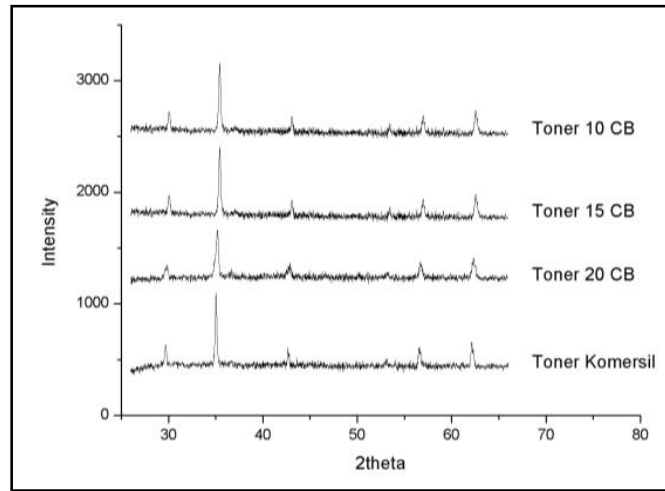

Gambar 4.8 Grafik Hasil Uji XRD Sampel Toner dengan Variasi CB

Hasil XRD juga menunjukkan pengaruh ukuran kristalit toner terhadap nilai suseptibilitas magnetiknya, semakin kecil serbuk toner, maka nilai suseptibilitas magnetiknya akan menurun. Hal ini disebabkan proses ball milling yang mempengaruhi perubahan letak dan arah spin magnet pada bahan akibat tertumbuknya bahan dengan bola-bola milling. Hal ini sesuai dengan penelitian yang telah dilakukan oleh Lestyowati $^{[19]}$.

\section{KESIMPULAN DAN SARAN}

\subsection{Kesimpulan}

Kesimpulan yang dapat diambil mengenai penelitian investigasi performa toner pada printer laser hasil variasi komposisi nano carbon black, berdasarkan data dan analisis yang telah dilakukan sebagai berikut:

1. Sintesis toner berbasis nano carbon black telah berhasil dibuat dengan menggunakan peralatan dalam skala laboratorium. Carbon black berukuran nanometer memiliki peran penting terhadap performa toner, baik sifat fisik (ukuran dan distribusi partikel) toner maupun kualitas (sifat adhesif dan densitas) toner. Berdasarkan hasil foto SEM, toner 10 wt\% CB hasil sintesis memiliki ukuran dan distrubusi yang seragam dibanding dengan toner 15 dan $20 \mathrm{wt} \% \mathrm{CB}$.

2. Nilai suseptibilitas magnetik toner hasil sintesis terbesar diberikan oleh toner 20 wt\% CB, yaitu sebesar $1,11 \times 10^{-4} \mathrm{~m}^{3} / \mathrm{kg}$, yang dimungkinkan karena butir $\mathrm{CB}$ yang lebih besar. Namun demikian, dengan mempertimbangkan hasil uji kualitas gambar dan adhesivitas. Performa terbaik ditunjukkan oleh toner $10 \mathrm{CB}$ hasil sintesis.

\section{DAFTAR PUSTAKA}

1. URL:http://www.idc.com/getdoc.jsp?contai nerId=prUK24220013. Diakses pada 10 Maret 2014

2. Banerjee, S. dan Wimpenny, D.I.. 2006. Laser Printing of Polymeric Materials. Rapid Prototyping and Manufacturing Group, Faculty of Computing Science and Engineering, DeMonfort University, Leicester, UK.

3. Wardani, P.Y.. 2013. Sintesis dan Karakterisasi Tinta Serbuk (TONER) berbahan baku Pasir Besi menggunakan $X R D$ dan SEM-EDAX. Skripsi, Jurusan Fisika Universitas Negeri Malang

4. Amon A. dan Bretler H.. Tinta Cetak dalam Bentuk Bubuk Kering. Paten Indonesia nomor P-003525. 
5. Schein, L.B.. Electrophotography and Development Physics. Springer Series in Electrophysics Volume 14, 1988, pp 36-41.

6. Ilmi, F.. 2013. Sintesis Tinta Kering (Toner) Menggunakan Bahan Baku Abu Ringan (Fly Ash) Sisa Pembakaran Batu Bara. Skripsi, Jurusan Fisika, Universitas Negeri Malang.

7. Irvan, M.. 2005. Karakterisasi Tinta Kering (Toner) dengan Metode Magnetik dan Scanning ElectronMicroscopy (SEM). Skripsi, FMIPA Institut Teknologi bandung.

8. Mark E. M., Chang, H., Cox, G.P. dan Leonardo J.L.. 2010. Toner Additives. Patent US 7687215 B2.

9. URL:http://www.gallifordconsulting.com/C hemically\%20Prpared\%20Toner\%20Basics .pdf Diakses pada 10 Maret 2014.

10. Tanaka, M., dan Kamiya, B.. Evaluation of Flow Properties of Toner Powder using Conical Rotor. Journal of Powder Technology Volume 181 (2008)pp 36-44.

11. Tanaka, M., Komagata M., Tsukada M. Kamiya H.. Fractal Analysis of the influence of Surface Roughness of Toner Particles on their Flow Properties and Adhesion Behavior. Journal of Powder Technology 186 (2008) pp 1-8.

12. Yamamoto, Y., Soda R., Kano J., Saito F.. Dispersion of Carbon Black by A Media Mill and Correlation of its Rate Constant with Beads Impact Energy. Journal of Powder Technology 219 (2012) pp 105110.

13. Lin, J.H.. Identification of the Surface Characteristics of Carbon Blacks by Pyrolysis GC-MASS. Carbon 40 (2002) pp 183-187.
14. Atif, M. Bongiovanni M., Giorcelli M., Celasco E., Tagliaferro A.. Modification and Characterization of Carbon Black with Mercaptopropyltrimethoxysilane. Applied Surface Science 286 (2013) pp 142-148.

15. Rochman, N.T.. 2013. Pengembangan Teknologi Pengolahan Pasir Besi menjadi Nano Partikel Black Oxide sebagai Bahan Baku Pigmen untuk Coating, Toner Printer dan Mesin Foto Copy. Universitas Teknologi Sumbawa.

16. Gregory, P.. 1991. High-Technology Applications of Organic Colorants, Plenum Press, New York.

17. Fink. 2013. Reactive Polymers Fundamentals and Applications. Elsevier.

18. Tanauma, A. dan Ferdy F.. Potensi Sumber Daya Alam Pasir Besi Pantai Arakan Kabupaten Minahasa Selatan. Jurnal Ilmiah Sains Vol.11 No.2 Oktober 2011.

19. Lestyowati, T.. 2013. Pengaruh Rasio $\mathrm{Fe}_{3} \mathrm{O}_{4}$ : $\mathrm{Fe}_{2} \mathrm{O}_{3}$, Rasio $\mathrm{Fe}$ : Cdan Ukuran Bulir Mineral Magnetik pada Suseptibilitas Magnetik Toner. Skripsi, Jurusan Fisika,Fakultas Matematika dan Ilmu pengetahuan Alam, Universitas Negeri Malang.

20. Kim S., Huh M., Yoon. 2004. Dry Toner Technology PVA Chemical Toner. Yeungnam University: School of Textile.

21. Vikman K., dan Sipi K.. Applicability of FTIR and Raman Spectroscopic Methods to The Study of Paper-Ink Interactions in Digital Prints", Journal Of Imaging Science And Technology Volume 47, Number 2, 2003 pp 146. 
P-ISSN: 2089-5925 E-ISSN: 2621-9328

Antrant

Jurnal Teknik Patra Akademika

PAre

Arademika

Volume 11 No. 01 Juli 2020 